\title{
First records of the red lionfish (Pterois volitans) in Martinique, French West Indies: monitoring invasion status through visual surveys
}

\author{
EWAN TRÉGARot ${ }^{1}$, MARINE FUMAROLI ${ }^{1}$, ALEXANDRE ARQUÉ ${ }^{1}$, CLAIRE HELLIO ${ }^{2}$ \\ AND JEAN-PHILIPPE MARÉCHAL ${ }^{1,3,4}$ \\ ${ }^{1}$ Observatoire du Milieu Marin Martiniquais, 14 rue Chéry-Rosette, Fond Lahaye, 97233 Schoelcher, Martinique, FWI, France, \\ ${ }^{2}$ LEMAR, Institut Universitaire Européen de la Mer, Université de Bretagne Occidentale, Technopôle Brest Iroise - rue Dumont \\ d'Urville, 29280 Plouzané, France, ${ }^{3}$ School of Biological Sciences, King Henry Building, University of Portsmouth, Portsmouth PO1 \\ ${ }_{2 D Y}$, UK, ${ }^{4}$ Nova Blue Environment, 14 rue Chéry-Rosette, Fond Lahaye, 97233 Schoelcher, Martinique, FWI, France
}

\begin{abstract}
The red lionfish (Pterois volitans) was first recorded in Martinique on 1 February 2011. Three years later, despite control measures to prevent the increase of lionfish population densities, the species is now well established. Maximum density has reached 1320 individuals $\mathrm{ha}^{-1}$ in some locations and the maximum fish size of $41 \mathrm{~cm}$ total length has been observed. A monitoring program was initiated by the Marine Institute of Martinique (OMMM) in 2011 to monitor the invasion and adjust local control efforts. Our results highlight how fast lionfish have been able to invade new littoral areas, especially hard bottom habitats. It took two years for them to completely colonize the west coast of Martinique, despite increasing capture efforts. It is expected that small-scale fisheries would target lionfish. Coastal ecosystems are clearly being subjected to a new threat, which may negatively affect local biodiversity.
\end{abstract}

Keywords: invasive species, Pterois volitans, Pterois miles, Martinique, Lesser Antilles, marine invasion

Submitted 22 April 2014; accepted 13 November 2014

\section{INTRDDUCTIDN}

Originally imported into the United States for the aquarium trade, the lionfish, Pterois volitans (Linnaeus, 1758) and Pterois miles (Bennett, 1828), often cited as the complex Pterois volitans/miles (Hamner et al., 2007; Whitfield et al., 2007; Freshwater et al., 2009), were accidentally released into the marine environment in the mid-1980s (Morris \& Akins, 2009). According to Freshwater et al. (2009), Pterois volitans spread rapidly across the Caribbean Sea and the Gulf of Mexico (Betancur-R et al., 2011; Johnston \& Purkis, 2011; Hackerott et al., 2013) and might be the only species of lionfish present in the Lesser Antilles (genetic studies are in progress). This species has become a major threat to coral reef biodiversity in the western Atlantic and the Caribbean, and represents one of the worst invasion scenarios in the marine environment (Côté et al., 2013; Green et al., 2013).

Marine coastal ecosystems are heavily threatened in Martinique (French West Indies) (Legrand et al., 2012). The lionfish is an additional new threat to native fishes and small crustaceans through predation and competition and it is about to disrupt the entire food chain (Green et al., 2012; Côté et al., 2013). Through visual, genetic and isotopic analyses from stomach contents, it has been shown that the feeding ecology of lionfish in the Caribbean is a concern as its prey list continues to increase (Morris \& Akins, 2009; Munoz et al., 2011; Valdez-Moreno et al., 2012; Côté et al., 2013). Thus the monitoring and surveying of the lionfish population in the coastal waters of Martinique was required.

In this paper we describe the first observation of lionfish in Martinique and quantify their population growth along the coast since 2011. We also describe the local strategy that was set up to respond to the increase in lionfish numbers, as advised in the Regional Lionfish Strategy Guide Book (Morris, 2012).

\section{MATERIALS AND METHDDS}

\section{Lionfish identification}

The lionfish species Pterois volitans and Pterois miles (order SCORPAENIFORMES, family SCORPAENIDAE) are originally from the Indo-Pacific Ocean. The two species are morphologically very similar, the only differences being the number of dorsal and anal fin soft rays (Schultz, 1986) and their mitochondrial DNA (Kochzius et al., 2003). Lionfish are easily distinguished from other native fish species of the same Scorpaenidae family in the Caribbean such as Scorpaena plumieri (Bloch, 1789). 


\section{Records of sightings and captures}

In February 2011, during the first stage of the invasion, a preliminary survey protocol was set up by the Marine Institute of Martinique (Observatoire du Milieu Marin Martiniquais OMMM) to record visual observations and captures from divers. After the colonization had extended along the coast of Martinique, we only recorded captures, in order to avoid double sightings. The table fields of the database were: Observer name; Category (diver, snorkeler, fisherman); Date of capture; Dive site name; Geographic coordinates (N, W); Depth; Estimated length of lionfish (size class); and Habitat. A dynamic map was produced to follow the removal rates of individuals in Martinique and is available online (http:// cartes.observatoire-eau-martinique.fr/poisson_lion/flash/). The size classes of individuals were estimated underwater - no accurate measurements were taken. The lionfish were killed underwater by volunteer divers and left in the ecosystem as a food source.

\section{Lionfish density assessment}

From March 2012 to July 2012, lionfish were counted visually by scuba-divers over $50 \times 5 \mathrm{~m}^{2}$ belt transects at depths of $5-$ $20 \mathrm{~m}$ (11 sites, 39 transects). Densities were calculated as the number of lionfish per hectare.

In 2013 , the survey area was increased to $50 \times 50 \mathrm{~m}^{2}$ quadrats to cover a larger portion of habitats, from the shallows to the bottom of the reef slope. Only coral reef and rocky shore habitats were sampled. Two divers delimited a surface of approximately $2500 \mathrm{~m}^{2}$ using two $50 \mathrm{~m}$ multi-decametres placed in parallel, $50 \mathrm{~m}$ from each other, from the shallows to the bottom of the reef or rocky bottom. The divers carefully scrutinized every square metre following an S-shaped pattern. Every lionfish was recorded and captured/killed if possible. The total length (size class) of each lionfish was assessed underwater and reported on a dive sheet, along with the depth and habitat type ( $\mathrm{N}=6848$ ind.). The captured fish were not precisely measured afterwards. Most of the data was provided by dive centres that were unable to provide any accurate measurements.

The quadrat surveys were conducted over five sites along the west coast. Sites were surveyed multiple times, but only the data that had been collected during the first visit was used to calculate the average density of each site, as the number of lionfish per hectare, to avoid the effect of removal on population densities (data not presented here).

\section{Age of the first lionfish observed in Martinique}

According to Barbour et al. (2011), the von Bertalanffy total length - weight formula has been used to calculate the age of the first lionfish observed in Martinique and to deduce the approximate date of arrival of that particular fish.

\section{RESULTS AND DISCUSSIDN}

The first lionfish reported in Martinique was on 1 February 2011 at Pointe de la Baleine $\left(14^{\circ} 31^{\prime} 08.12^{\prime \prime} \mathrm{N}-\right.$ $61^{\circ} 05^{\prime} 51.09^{\prime \prime} \mathrm{W}$ ), Anses d'Arlet (Figure 1). The specimen was spotted and photographed at $6 \mathrm{~m}$ depth in a habitat composed of large rock blocks and its total length was visually estimated to be $150 \mathrm{~mm}$; however, due to a lack of adequate equipment, the diver was unable to catch this fish. Using the size equations developed by Barbour et al. (2011), it was calculated that a $150 \mathrm{~mm}$-long lionfish specimen would be approximately five months old, suggesting that this individual would have initially settled on the reef as a juvenile recruit in Martinique in September 2010.

Martinique was one of the last islands in the Lesser Antilles to be colonized by the lionfish (the first sighting was made in 2011, see Figure 2A, B). Guadeloupe and Dominica (two northern islands) recorded lionfish presence slightly before Martinique, on the 25 October 2010 in Guadeloupe (first specimen captured by the National Park) and on the 27 January 2011 in Dominica (first specimen captured confirmed by the Fisheries Division), whilst the first record in Saint-Lucia was made in October 2011 and the first catch was in November the same year.

The north to south progression of the lionfish through the Lesser Antilles remains unexplained as the major currents travel north and the flow from the Atlantic Ocean to the Caribbean Sea goes east to west (Shulman \& Bermingham, 1995; Roberts, 1997). We would have expected the lionfish in the Lesser Antilles to have originated from the south, as the occurrence of the species was established in the Dutch Antilles (Curaçao, Bonaire) in October 2009 (de León et al., 2013).

After February 2011, lionfish observations in Martinique were recorded in the vicinity of the Fort de France Bay, and sightings progressed northward along the west coast. No records from the south coast had been registered before December 2011 (Figure 1).

The fact that the population extended from the central Fort de France Bay in Martinique raised the question as to whether the first larvae were introduced from the ballast water of commercial ships, the maritime traffic being quite intense in this area of the Lesser Antilles. However, no successful introductions of Scorpaenids are known to have occurred via ballast water (Hare \& Whitfield, 2003). Another explanation for this extension could be the higher probability of detecting a lionfish in this area due to habitat type, hydrodynamism and search efforts. It could also be hypothesized that the occurrence of lionfish on the reefs of the south coast of Martinique late in 2011 might have been offspring of populations from Saint Lucia, transported by the north-headed current in that area.

Nine habitats were identified from the database: Rock reef; Rocky shore; Patch rock reef; Coral Reef; Artificial Structure; Sand; Algal community; Seagrass; and Mangrove. Clustering was performed to address the patterns of distribution according to habitat, size of individuals and depth $(\mathrm{N}=6848$ captures). Three homogenous groups were identified (Table 1).

While it appears that the preferential habitat for lionfish is hard bottom substrate, regardless of depth, the share of the dominant size class increases with depth, confirming the suggestion by Claydon et al. (2012) that lionfish settle in shallow habitats for shelter before moving to deep reefs. This outcome might also reflect a more efficient control effort in shallow waters than in deeper waters where lionfish reach larger sizes.

As a consequence of successful recruitment, lionfish have been found in all of the marine ecosystems on the west coast of Martinique: reef (95.3\% of catches); seagrass (0.37\%); and mangrove (0.06\%). These results show a high preference for hard bottom habitats ( 480 ha $-14.7 \%$ of 


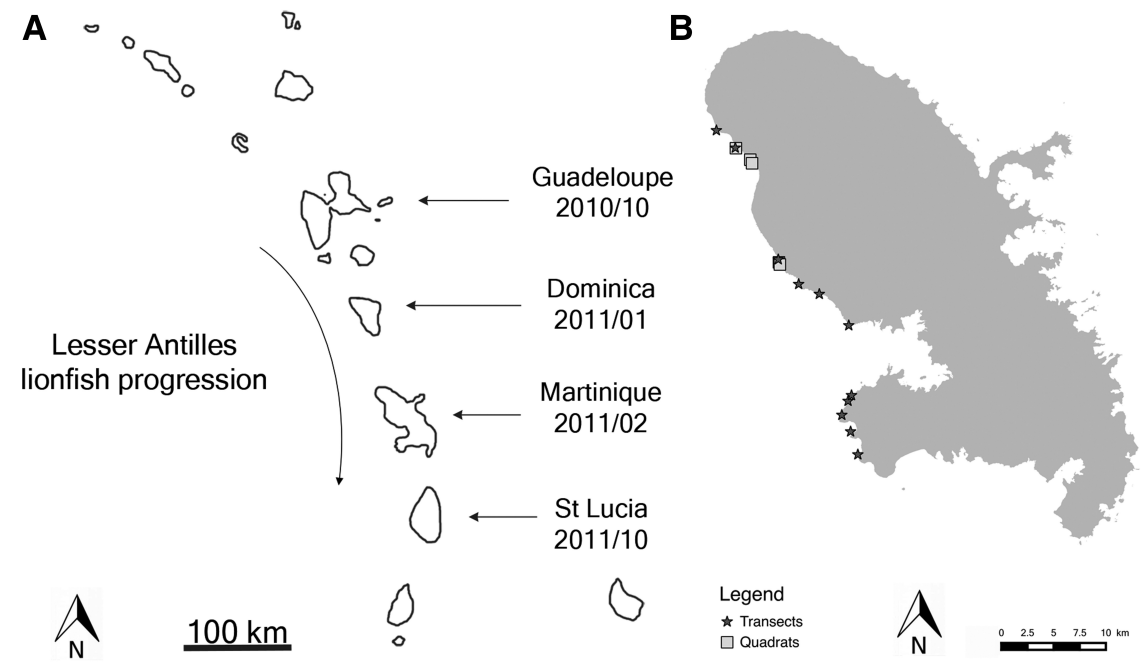

Fig. 1. Extent of lionfish invasion in Martinique vs time - from the early stage of colonization in 2011 to January 2014 (observation/capture data provided by divers). Each dot represents at least a single capture.

total habitats) and suggest that seagrass beds (1360 ha $41.6 \%$ of total habitats) and mangroves are used as transitional habitats, as compared to other studies (Barbour et al., 2010; Claydon et al., 2012; Pimiento et al., 2013). However, sampling efforts in seagrass beds and mangroves have been lower than that in hard bottom habitats. The mangrove habitat is quite unusual for the lionfish, as previously mentioned by Barbour et al. (2010). Four lionfish (size class $[15-20 \mathrm{~cm}]$ ) were found together in the root systems of the Fort-de-France Bay mangroves in Martinique during a one person-hour exploration survey. This data from Martinique's mangrove represents a significant record for population density - eight times more than that of San Salvador's mangrove (Bahamas) (Pimiento et al., 2013). While the catch per unit effort is fairly even between reef and mangrove habitats in San Salvador, it can be extremely high in Martinique reefs (up to 75 lionfish in one person-hourpersonal record).

Seagrass beds constitute the major habitat along the Caribbean coast of Martinique, where only 25 captures of lionfish have been reported, also reflecting a low sampling effort in this ecosystem. Generally, the habitat preferences of lionfish are sponges, wooden logs or any artificial structures providing shelter in seagrass. Lionfish are hardly ever observed directly on seagrass and densities are certainly higher if structures are $<_{3} \mathrm{~m}$ in diameter, which are not considered as specific habitats according to Claydon et al. (2012).

The lionfish population in Martinique had dramatically increased on the west coast by January 2012, from single sporadic observations to over 1500 captures per month in late 2013 (Figure 3). While relatively few sightings have been reported by fishermen (fish traps - down to $120 \mathrm{~m} \mathrm{depth}$ ) from the Atlantic east coast (Figure 1), the area has not been sampled consistently nor efficiently due to difficult and dangerous sea conditions. Thus, the lionfish population on the east coast might be high. However, data from the Saint Martin Marine Reserve (north Lesser Antilles) located on the windward coast of the island tends to show that the lionfish population densities are quite low compared to the leeward coast of other islands of the archipelago (data not presented here). Rough environmental sea conditions on exposed coasts might limit the spread of lionfish populations in Atlantic reefs and other habitats.

The average population density in coral reefs and rocky habitats, calculated from $50 \times 5 \mathrm{~m}^{2}$ belt transect data in 2012, was $14.7 \pm 0.8$ individuals ha ${ }^{-1}(\mathrm{~N}=39)$; however, this value has to be taken carefully - Green et al. (2013) have highlighted that belt transects are not the most efficient method for measuring lionfish densities, as individuals tend to aggregate in patchy distributions. By February 2013, lionfish densities were assessed using $50 \times 50 \mathrm{~m}^{2}$ quadrats, giving an average value of $118 \pm 24$ individuals $\mathrm{ha}^{-1}$, but densities might have been even higher given the cryptic behaviour of lionfish (Kulbicki et al., 2012). In July 2013, density reached 66 fish over $500 \mathrm{~m}^{2}$ (1320 individuals ha ${ }^{-1}$ ) on another site (quadrat survey) south of the Saint Pierre Bay (north Caribbean). This site is a rocky reef surrounded by a steep slope slit and a sandy bottom. Surveys occurred at a depth of between 13 and $20 \mathrm{~m}$ over $500 \mathrm{~m}^{2}$. The average lionfish density in 2013 was 480 individuals ha ${ }^{-1}(\mathrm{~N}=5$ calculated with the density value of the first quadrat survey - without lionfish removal effect).

After three years, the lionfish population densities in Martinique are almost equivalent to those found in the Bahamas when they invaded in the early 2000s. These values are significantly above the values found in their native range (Table 2 ).

Scuba-diving capture campaigns started in May 2011 in cooperation with dive centres in Martinique and were coordinated by OMMM. Dive centres are evenly distributed along the west coast of Martinique and, thus, observations are considered consistent along the coast and reports from the dive centres reflect, in part, the spread of the lionfish population. As of 2014, a few dive centres were actively controlling lionfish populations near dive sites. No significant information on fishermen catches in fish traps or nets in Martinique has been reported. During 2011, the invasion had been slow, as indicated by the low number of divers' observations (16 individuals observed in November 2011). Assuming that the visual census effort from divers has been equivalent during the years 2011 and 2012, a strong colonization phase of lionfish started in December 2011, with a peak in July 2012, with acceleration 


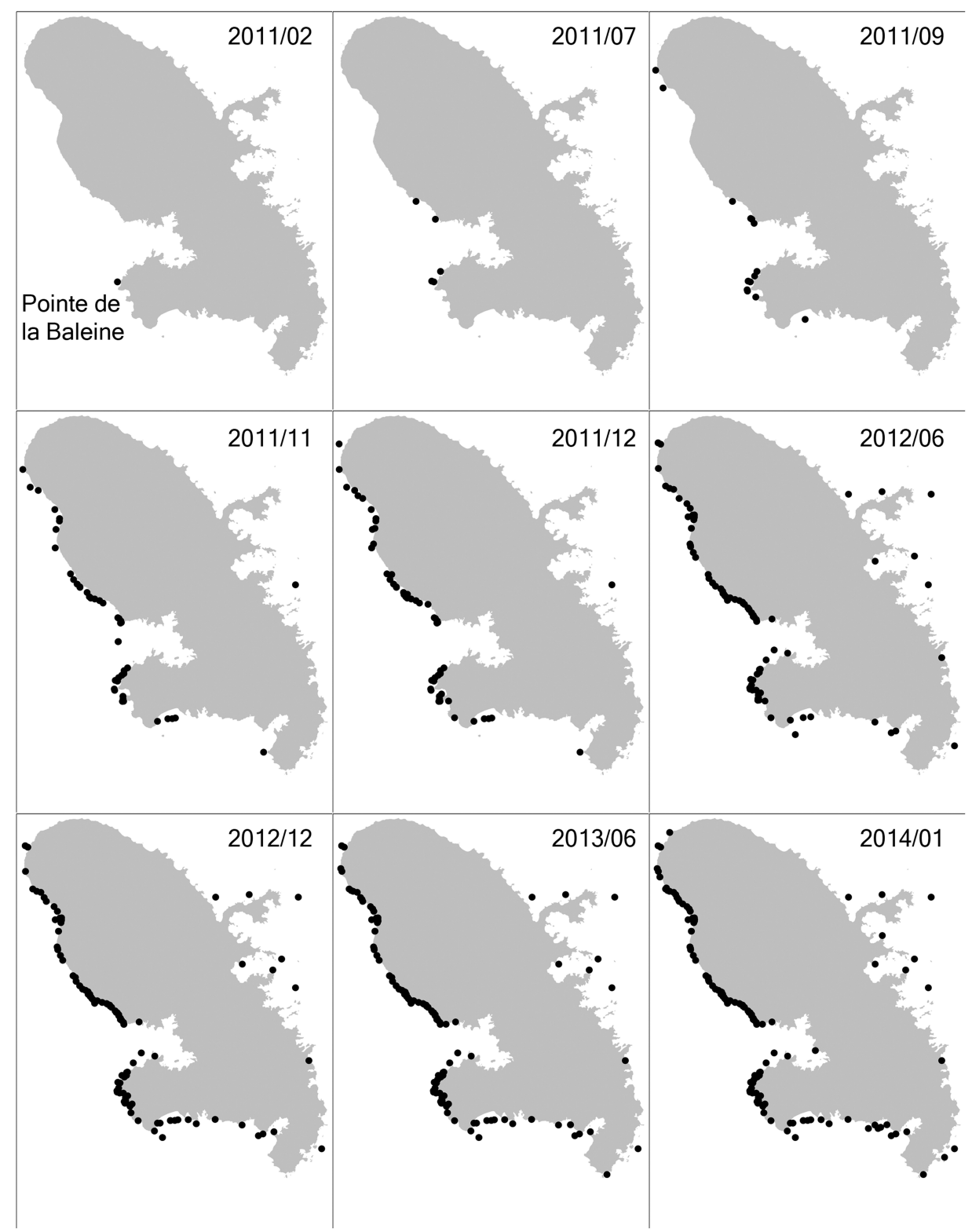

Fig. 2. (A) North-south regional progression of lionfish in the Lesser Antilles. (B) Transect and quadrat locations along the west coast of Martinique.

during the following months (70 catches in January 2012, 540 in January 2013 and 1502 in December 2013). Capture records were regularly updated as it has been stated by Morris (2012)

Table 1. Clusters analysis similarities between groups of lionfish in Martinique ( $\mathrm{N}=6848$ captures).

\begin{tabular}{|c|c|c|c|c|c|}
\hline & Cluster & $\mathbf{N}$ & $\begin{array}{l}\text { Dominant } \\
\text { habitat (\% of } \\
\text { catches) }\end{array}$ & $\begin{array}{l}\text { Major size } \\
\text { class (\%) }\end{array}$ & $\begin{array}{l}\text { Average } \\
\text { depth }(\mathrm{m})\end{array}$ \\
\hline \multirow[t]{2}{*}{ Group 1} & $\mathrm{C}_{1}$ & 1640 & Rocky shore: 49 & {$[10-15 \mathrm{~cm}]: 40$} & 6.3 \\
\hline & C6 & 1330 & Rock reef: 52 & {$[10-15 \mathrm{~cm}]: 28$} & $7 \cdot 3$ \\
\hline \multirow[t]{2}{*}{ Group 2} & $\mathrm{C}_{5}$ & 1423 & Rock reef: 63 & {$[15-20 \mathrm{~cm}]: 28$} & 16.6 \\
\hline & $\mathrm{C}_{2}$ & 1592 & Rock reef: 71 & {$[15-20 \mathrm{~cm}]: 30$} & 16.5 \\
\hline \multirow[t]{2}{*}{ Group 3} & $\mathrm{C}_{3}$ & 180 & $\begin{array}{l}\text { Artificial } \\
\text { structure: } 37\end{array}$ & {$[25-30 \mathrm{~cm}]: 32$} & 42.5 \\
\hline & $\mathrm{C}_{4}$ & 683 & Rock reef: 47 & {$[15-25 \mathrm{~cm}]^{\mathrm{a}}: 60$} & 26.6 \\
\hline
\end{tabular}

${ }^{\mathrm{a}}$ In Group 3 both $[15-20 \mathrm{~cm}]$ and $[20-25 \mathrm{~cm}]$ classes represented $30 \%$ and were pooled. that an eventual invasion peak should be followed by an equilibrium. From May 2011 to February 2014, 12,300 lionfish were officially captured in Martinique, and this equilibrium has not yet been reached (Figure 3 ).

The maximum size of captured lionfish also increased, with individuals belonging to the $41-45 \mathrm{~cm}$ size class (Figure 3 ), which is bigger than their natural size range: Pterois volitans - $38 \mathrm{~cm}$ (Darling et al., 2011). The number of catches of lionfish that fall within the size classes of $21-25 \mathrm{~cm}$ and $26-$ $30 \mathrm{~cm}$ had increased by the end of 2012 , but the majority of the fish captured were from the $11-15 \mathrm{~cm}$ and $16-20 \mathrm{~cm}$ size classes, corresponding to fish that are sexually mature (Morris \& Whitfield, 2009).

Figure 4 reflects the succession of the percentage of the size class frequency vs time between October 2011 and February 2013 (17 month period) obtained from captured fish (divers were told to target all fish sizes). The number of captures remained below 100 individuals until June 2012. Even if the numbers of fish were low during the first year of invasion, 


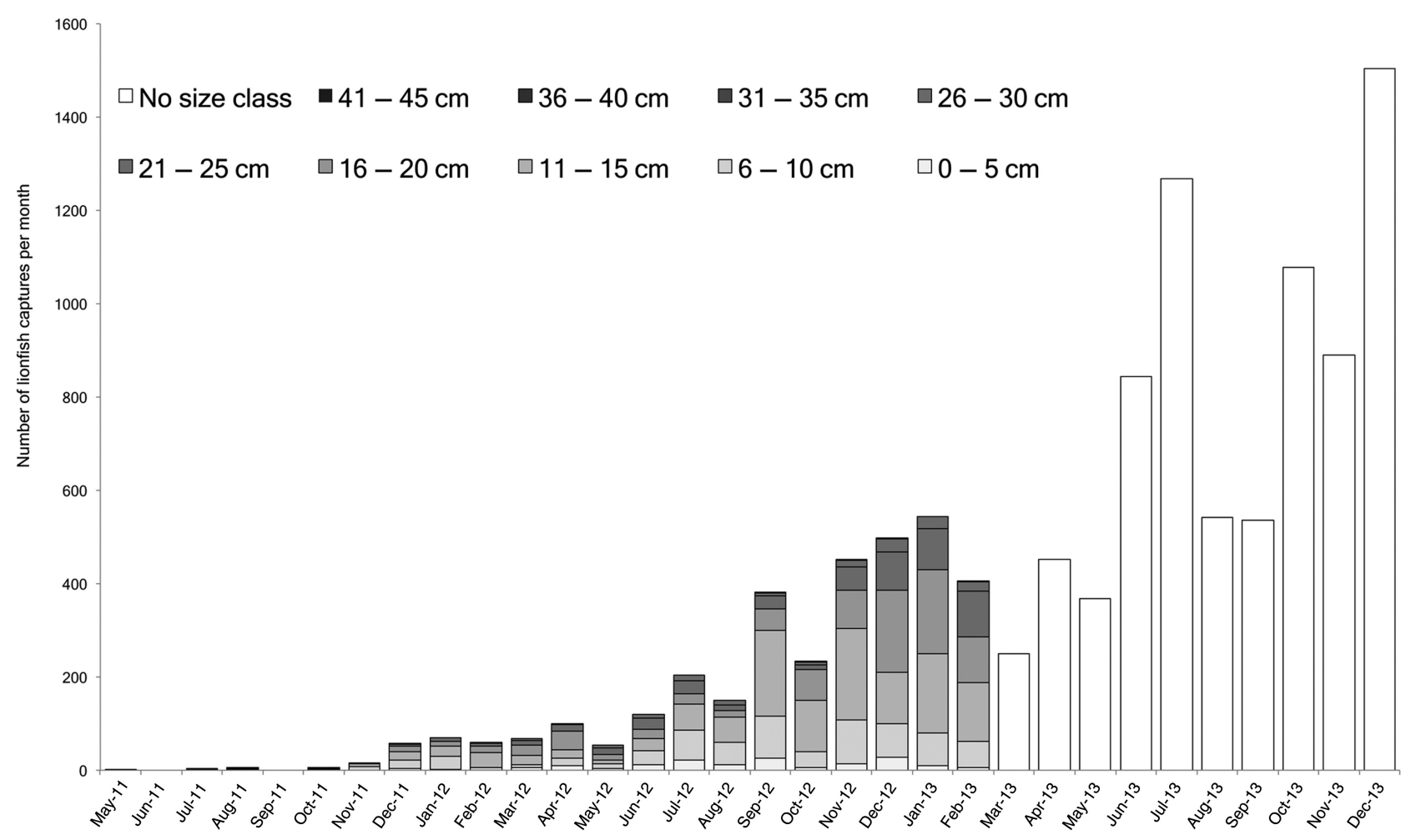

Fig. 3. Size class distribution of captured lionfish in Martinique from May 2011 to February 2013 (size classes: $0-5 \mathrm{~cm} ; 6-10 \mathrm{~cm} ; 11-15 \mathrm{~cm}$; $16-20 \mathrm{~cm}$; $21-$ $25 \mathrm{~cm} ; 26-30 \mathrm{~cm} ; 31-35 \mathrm{~cm} ; 36-40 \mathrm{~cm} ; 41-45 \mathrm{~cm}$ ). Since March 2013 , the numbers of lionfish captured per dive became too high for any volunteer to collect data on size class, depth and habitat.

there is a displacement within the size class frequencies between October 2011 and May-June 2012 towards an increase in larger fish within the population structure. The smaller fish frequency started to increase again by March 2012, representing the dominant size class by September 2012 and a significant size class of $16-20 \mathrm{~cm}$ was presented by December 2012, which would suggest two cohorts of lionfish by early 2013.

In response to the invasion of lionfish in Martinique, OMMM has set up a French Antilles network in cooperation

Table 2. Lionfish densities evaluated in their natural distribution area and invasive range in the Caribbean.

\begin{tabular}{|c|c|c|}
\hline Areas of study & $\begin{array}{l}\text { Lionfish density } \\
\text { (ind. } \mathrm{ha}^{-1} \text { ) }\end{array}$ & Authors \\
\hline Indo-Pacific & 26 & Kulbicki et al. (2012) \\
\hline Palau Archipelago & $<14$ & Grubich et al. (2009) \\
\hline Kenya & 25 & Darling et al. (2011) \\
\hline North Carolina & $\begin{array}{l}21(2004) \\
150 \text { on average (2008) } \\
\text { Max } 450(2008)\end{array}$ & $\begin{array}{l}\text { Whitfield et al. (2007) } \\
\text { Morris \& Whitfield (2009) }\end{array}$ \\
\hline Bahamas & $\begin{array}{l}\text { 100 on average }(2008) \\
\text { Max } 393(2008) \\
440 \text { on average }(2012) \\
\text { Max } 5200(2012)\end{array}$ & $\begin{array}{l}\text { Darling et al. (2011) } \\
\text { Green \& Côté (2009) } \\
\text { Hackerott et al. (2013) }\end{array}$ \\
\hline Cuba & $150(2012)$ & Hackerott et al. (2013) \\
\hline Belize & $160(2012)$ & Hackerott et al. (2013) \\
\hline Bonaire & 66 on average (2013) & de León et al. (2013) \\
\hline Curaçao & 127 on average (2013) & \\
\hline Martinique & $\begin{array}{l}480 \text { on average }(2013) \\
\text { Max } 1320(2013)\end{array}$ & \\
\hline
\end{tabular}

with the local authorities to develop a population control strategy. This strategy defines four objectives, public awareness, control strategies, monitoring and research, and is inspired by the Regional Caribbean Lionfish Strategy. Manual removal is the only option for controlling invasive lionfish population to date and it has been shown that local removal can be effective (Morris, 2012). Based on Green \& Côté (2009), removing all individuals greater than $15 \mathrm{~cm}$ in total length from one site reduces the consumption capacity of the remaining population to levels that are far surpassed by the production of their prey, and would therefore be sustainable.

Removal not only helps maintain a lower lionfish population, but it also avoids a decline in native prey fish communities caused by lionfish predation. However, Green et al. (in press) demonstrated that adult lionfish population thresholds predicted to cause predation-induced declines are required to maintain sustainable juvenile reef fish assemblages and biomasses, but are mostly site-specific. Other models revealed that large numbers of lionfish would need to be removed regularly to result in a significant decrease in the overall population; it has been stated by Morris et al. (2011) that $27 \%$ of the adult population should be removed every month while Barbour et al. (2011) mentioned that a rate of $15-65 \%$ removal of the total population each year would be necessary to control lionfish population development region-wide.

Lionfish populations have reached maximum densities of 1320 individuals $\mathrm{ha}^{-1}$ in coastal waters of Martinique, illustrating a concentration effect on isolated rocky reefs. Continuous effort is required to increase catches. An agreement has been recently released in Martinique by the local authorities to encourage lionfish catches by the local small-scale fisheries, 


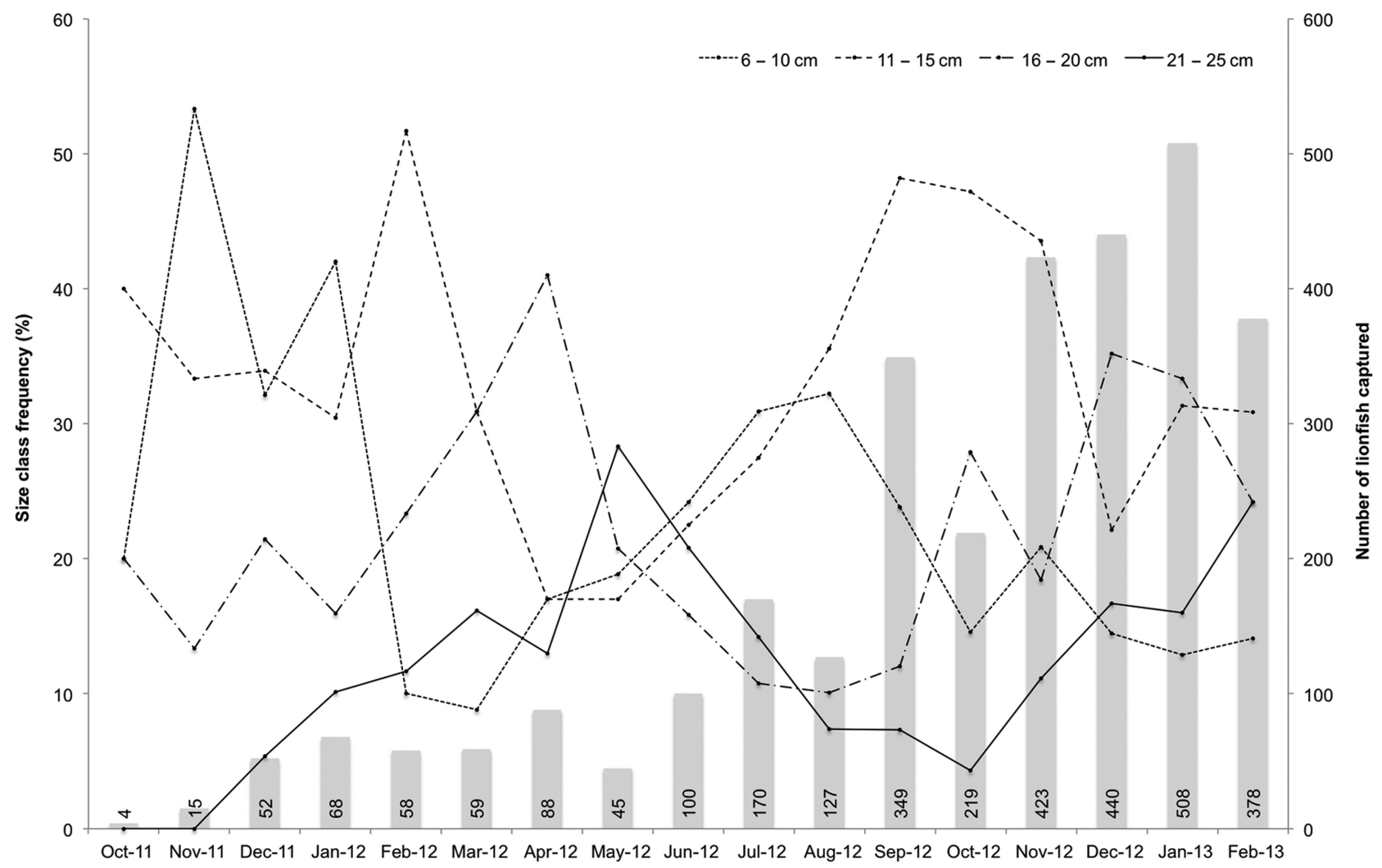

Fig. 4. Lionfish size class frequency vs time in Martinique (dashed lines). Only size classes with individuals recorded every month between October 2011 and February 2013 are presented $(6-10 \mathrm{~cm} ; 11-15 \mathrm{~cm} ; 16-20 \mathrm{~cm} ; 21-25 \mathrm{~cm})$. Bars illustrate the number of lionfish captured each month.

under certain conditions, excluding the coastal areas of the west coast polluted with the banana pesticide chlordecone (Coat et al., 2006). On northern islands, the ciguatera contamination of lionfish (Robertson et al., 2013) might restrict the catches and lionfish may be added to the list of banned fishes (http://www.poissonlion-antillesfrancaises.com/workshop/ciguatera/). Local fishing restrictions will restrain the lionfish population control efforts. It is therefore expected that fishing gear would be required to specifically target lionfishes, especially to remove lionfish from marine protected areas. Maintaining low-density population levels seems to be the best current option to mitigate the ecological and socioeconomic impacts of the lionfish invasion.

\section{ACKNOWLEDGEMENTS}

The authors would like to thank the Ministère de l'Ecologie, du Développement durable et de l'Energie for funding the PoLiPA project (SNB-2012), the DEAL Martinique (Direction de l'Environnement, de l'Aménagement et du Logement) for funding the initial lionfish program (IFRECOR French Coral Reef Initiative) and all the dive centres endeavouring to help control the lionfish invasion.

\section{REFERENCES}

Barbour A.B., Allen M.S., Frazer T.K. and Sherman K.D. (2011) Evaluating the potential efficacy of invasive lionfish (Pterois volitans) removals. Plos One 6(5), e19666, doi: 10.1371/journal.pone.0019666.
Barbour A.B., Montgomery M.L., Adamson A.A., Díaz-Ferguson E. and Silliman B.R. (2010) Mangrove use by the invasive lionfish Pterois volitans. Marine Ecology Progress Series 401, 291-294.

Betancur-R R., Hines A., Acero A., Orti G., Wilbur A.E. and Freshwater D.W. (2011) Reconstructing the lionfish invasion: insights into Greater Caribbean biogeography. Journal of Biogeography 38, $1281-1293$.

Claydon J.A.B., Calosso M.C. and Traiger S.B. (2012) Progression of invasive lionfish in seagrass, mangrove and reef habitats. Marine Ecology Progress Series 448, 119-129.

Coat S., Bocquené G. and Godard E. (2006) Contamination of some aquatic species with the organochlorine pesticide chlordecone in Martinique. Aquatic Living Resources 19, 181-187.

Côté I.M., Green S.J., Morris J.A. Jr, Akins J.L. and Steinke D. (2013) Diet richness of invasive Indo-Pacific lionfish revealed by DNA barcoding. MEPS 472, 249-256.

Darling E.S., Green S.J., O'Leary J.K. and Cote I.M. (2011) Indo-Pacific lionfish are larger and more abundant on invaded reefs: a comparison of Kenyan and Bahamian lionfish populations. Biological Invasions 13, 2045-2051.

de León R., Vane K., Bertuol P., Chamberland V.C., Simal F., Imms E. and Vermeij M.J.A. (2013) Effectiveness of lionfish removal efforts in the southern Caribbean. Endangered Species Research 22, 175-182.

Freshwater D.W., Hines A., Parham S., Wilbur A., Sabaoun M., Woodhead J., Akins L., Purdy B., Whitfield P.E. and Paris C.B. (2009) Mitochondrial control region sequence analyses indicate dispersal from the US East Coast as the source of the invasive Indo-Pacific lionfish Pterois volitans in the Bahamas. Marine Biology $156,1213-1221$. 
Green S. and Côté I. (2009) Record densities of Indo-Pacific lionfish on Bahamian coral reefs. Coral Reefs 28, 107.

Green S., Tamburello N., Miller S., Akins J. and Côté I. (2013) Habitat complexity and fish size affect the detection of Indo-Pacific lionfish on invaded coral reefs. Coral Reefs 32(2), 413-421.

Green S.J., Akins J.L., Maljković A. and Côté I.M. (2012) Invasive lionfish drive Atlantic coral reef fish declines. Plos One 7, e32596.

Green S.J., Dulvy N.K., Brooks A.L.M., Akins J.L., Cooper A.B., Miller S. and Côté I.M. (2104) Linking removal targets to the ecological effects of invaders: a predictive model and field test. Ecological Applications 24, 1311-1322, http://dx.doi.org/10.1890/13-0979.1.

Grubich J., Westneat M. and McCord C. (2009) Diversity of lionfishes (Pisces: Scorpaenidae) among remote coral reefs of the Palau Archipelago. Coral Reefs 28, 807 .

Hackerott S., Valdivia A., Green S.J., Côté I.M., Cox C.E., Akins L., Layman C.A., Precht W.F. and Bruno J.F. (2013) Native predators do not influence invasion success of pacific lionfish on Caribbean reefs. Plos One 8, e68259.

Hamner R.M., Freshwater D.W. and Whitfield P.E. (2007) Mitochondrial cytochrome b analysis reveals two invasive lionfish species with strong founder effects in the western Atlantic. Journal of Fish Biology 71, 214-222.

Hare J.A. and Whitfield P.E. (2003) An integrated assessment of the introduction of lionfish (Pterois volitans/miles complex) to the Western Atlantic Ocean. NOAA Technical Memorandum, NOS $\operatorname{NCCOS~2,~} 21$.

Johnston M.W. and Purkis S.J. (2011) Spatial analysis of the invasion of lionfish in the western Atlantic and Caribbean. Marine Pollution Bulletin 62, 1218-1226.

Kochzius M., Söller R., Khalaf M.A. and Blohm D. (2003) Molecular phylogeny of the lionfish genera Dendrochirus and Pterois (Scorpaenidae, Pteroinae) based on mitochondrial DNA sequences. Molecular Phylogenetics and Evolution 28, 396-403.

Kulbicki M., Beets J., Chabanet P., Cure K., Darling E., Floeter S.R., Galzin R., Green A., Harmelin-Vivien M., Hixon M., Letourneur Y., Lison de Loma T.L., McClanahan T., McIlwain J., Mou-Tham G., Myers R., O'Leary J.K., Planes S., Vigliola L. and Wantiez L. (2012) Distribution of Indo-Pacific lionfishes Pterois spp. in their native ranges: implications for the Atlantic invasion. Marine Ecology Progress Series 446, 189-205.

Legrand H., Lenfant P., Sotheran I.S., Foster-Smith R.L., Galzin R. and Marechal J.-P. (2012) Mapping marine benthic habitats in Martinique (French West Indies). Caribbean Journal of Science 46, 267-282.

Morris J.A. (2012) Invasive lionfish: a guide to control and management. Marathon, Florida: Caribbean Fisheries Institute, Special Publication Series, Number 1, $113 \mathrm{pp}$.
Morris J.A. and Akins J.L. (2009) Feeding ecology of invasive lionfish (Pterois volitans) in the Bahamian archipelago. Environmental Biology of Fishes 86, 389-398.

Morris J.A., Shertzer K.W. and Rice J.A. (2011) A stage-based matrix population model of invasive lionfish with implications for control. Biological Invasions 13, 7-12.

Morris J.A. and Whitfield P.E. (2009) Biology, ecology, control and management of the invasive Indo-Pacific lionfish: an updated integrated assessment. NOAA Technical Memorandum NOS NCCOS 99, 1-57.

Munoz R.C., Currin C.A. and Whitfield P.E. (2011) Diet of invasive lionfish on hard bottom reefs of the Southeast USA: insights from stomach contents and stable isotopes. Marine Ecology-Progress Series 432, $181-193$.

Pimiento C., Nifong J.C., Hunter M.E., Monaco E. and Silliman B.R. (2013) Habitat use patterns of the invasive red lionfish Pterois volitans: a comparison between mangrove and reef systems in San Salvador, Bahamas. Marine Ecology 1-10, doi: 10.1111/maec.12114.

Roberts C.M. (1997) Connectivity and management of Caribbean coral reefs. Science 278, 1454-1457.

Robertson A., Garcia A.C., Flores Quintana H.A.F., Smith T.B., Castillo B.F. II, Reale-Munroe K., Gulli J.A., Olsen D.A., Hooe-Rollman J.I., Jester E.L.E., Klimek B.J. and Plakas S.M. (2013) Invasive lionfish (Pterois volitans): a potential human health threat for ciguatera fish poisoning in tropical waters. Marine Drugs $12,88-97$.

Schultz E.T. (1986) Pterois volitans and Pterois miles: two valid species. Copeia 3, 686-69o.

Shulman M.J. and Bermingham E. (1995) Early life histories, ocean currents, and the population genetics of Caribbean reef fishes. Evolution 49, 897-910.

Valdez-Moreno M., Quintal-Lizama C., Gómez-Lozano R. and García-Rivas M. (2012) Monitoring an Alien invasion: DNA barcoding and the identification of lionfish and their prey on coral reefs of the Mexican Caribbean. Plos One 7, e36636.

and

Whitfield P.E., Hare J.A., David A.W., Harter S.L., Munoz R.C. and Addison C.M. (2007) Abundance estimates of the Indo-Pacific lionfish Pterois volitans/miles complex in the Western North Atlantic. Biological Invasions 9, 53-64.

Correspondence should be addressed to: J.-P. Maréchal Nova Blue Environment 14 rue Chéry-Rosette, Fond Lahaye, 97233 Schoelcher Martinique, FWI, France email: marechal.jean@gmail.com 